\title{
ASPECTS OF GEODIVERSITY OF PALAEOZOIC LIMESTONES IN THE BLACK MOUNTAINS OF SOUTHERN FRANCE
}

Christian Giusti

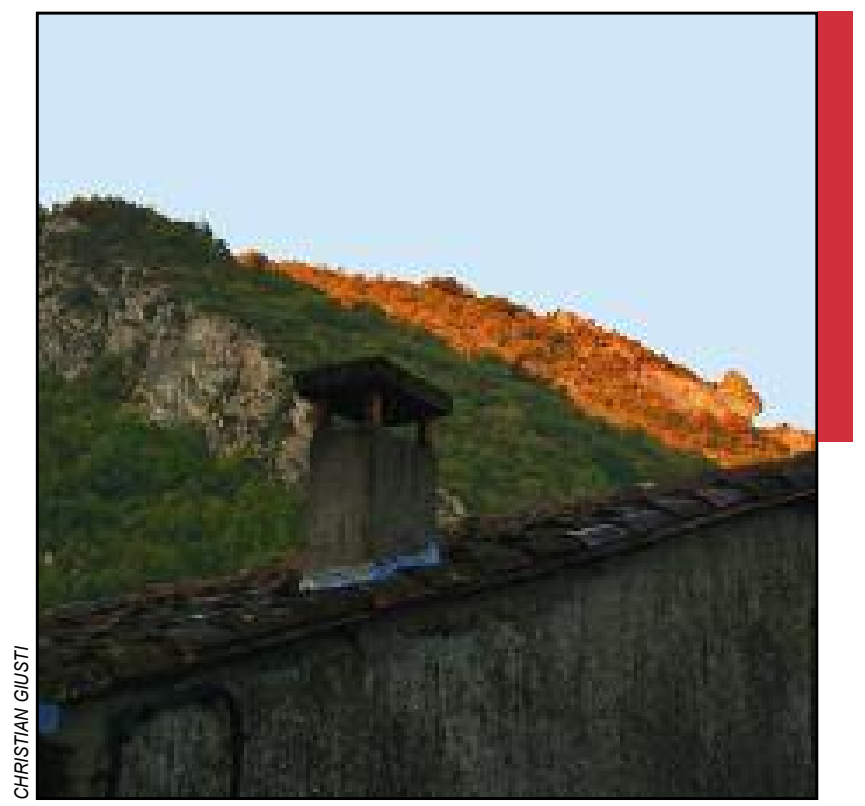

The sun rising on the Cambrian limestone massif of Dent de Saint Jean, Brusque, Aveyron. 


\title{
Aspects of geodiversity of Palaeozoic limestones in the Black Mountains of southern France
}

DOI: http://dx.doi.org/10.3986/AGS.963

UDC: 911.2:551.4(44-13)

821.111.09TOLKIEN J.R.R.

COBISS: 1.01

ABSTRACT: In the southern Massif Central (France), where the scenery resembles that of Middle-earth, the geodiversity of carbonate formations (limestones and dolomites), mainly of Paleozoic age, can be observed in the nested scales of the geotopes, geofacies, and geosystems.

KEYWORDS: geography, geology, geomorphology, geodiversity, Black Mountains (Montagne Noire), Tolkien, France

This article was submitted for publication on October $9^{\text {th }}, 2014$.

\author{
ADDRESS: \\ Christian Giusti, Ph.D. \\ Department of Geography and Land Use Planning, University of Paris-Sorbonne \\ ENeC Lab »Espaces, Nature \& Culture«, UMR 8185 CNRS \\ 191 rue Saint-Jacques F - 75005 Paris, France \\ E-mail: Christian.Giusti@paris-sorbonne.fr
}




\section{Introduction}

In one of the best-known works of the twentieth century literature, The Lord of the Rings, the action of each of the six books of this long story unfolds through the stunning landscapes of Middle-earth, which are underpinned by great geodiversity (Gray 2013). One of the most important sites of Tolkien's world, Rivendell, Imladris, the »last homely house east of the sea « (Rivendell illustration ... 2014), is located in a hidden trough alongside a narrow valley flanked by high limestone walls dotted with waterfalls, a landform feature whose model is clearly the Lauterbrunnen Valley, as the writer himself stated in a letter to his son Michael (Tolkien 1981, 306). As noted by Marie Barnfield (1996), »not only the similarity between Tolkien's painting of Rivendell and the Lauterbrunnen Valley, but also: i) that Tolkien had visited Lauterbrunnen in 1911, ii) that he had come down into the valley by an unusual route that exactly mirrors the rather perverse route his characters insist on taking into Rivendell, iii) that Lauterbrunnen essentially means the same as Greyflood \& Hoarwell, and iv) that Tolkien mirrored the sound of the name Lauterbrunnen itself in the English and Elvish names for the Rivendell river: i.e. Loudwater \& Bruinen." All over the Alps and Jura Mountains (Figure 1), more or less similar landforms associated with outcrops of limestone rocks are to be found, such as the Arve Valley between Sallanches and Cluses in the Savoy Alps, the Mesdì Valley (Ital. Val de Mesdi) in the Dolomites, and the blind valley of Baume-les-Messieurs in the Jura Mountains, which inspired the illustrator John Howe (2014).

This essay is a tribute to our late distinguished colleague Bojan Erhartič. We had the pleasure of meeting twice in Paris, first at the "Geomorphosites 2009 « symposium with several papers on geomorphosites in Slovenia (as first author) on natural heritage and on karst geotourism, and second in August 2013 at the Eighth International Conference on geomorphology, during which Bojan participated on the fieldtrip to the Seine Valley (Figure 2). Because he was from Slovenia, Bojan had a keen interest in the study of karst systems and the magnificence of limestone landscapes in the Alps and the Jura Mountains.

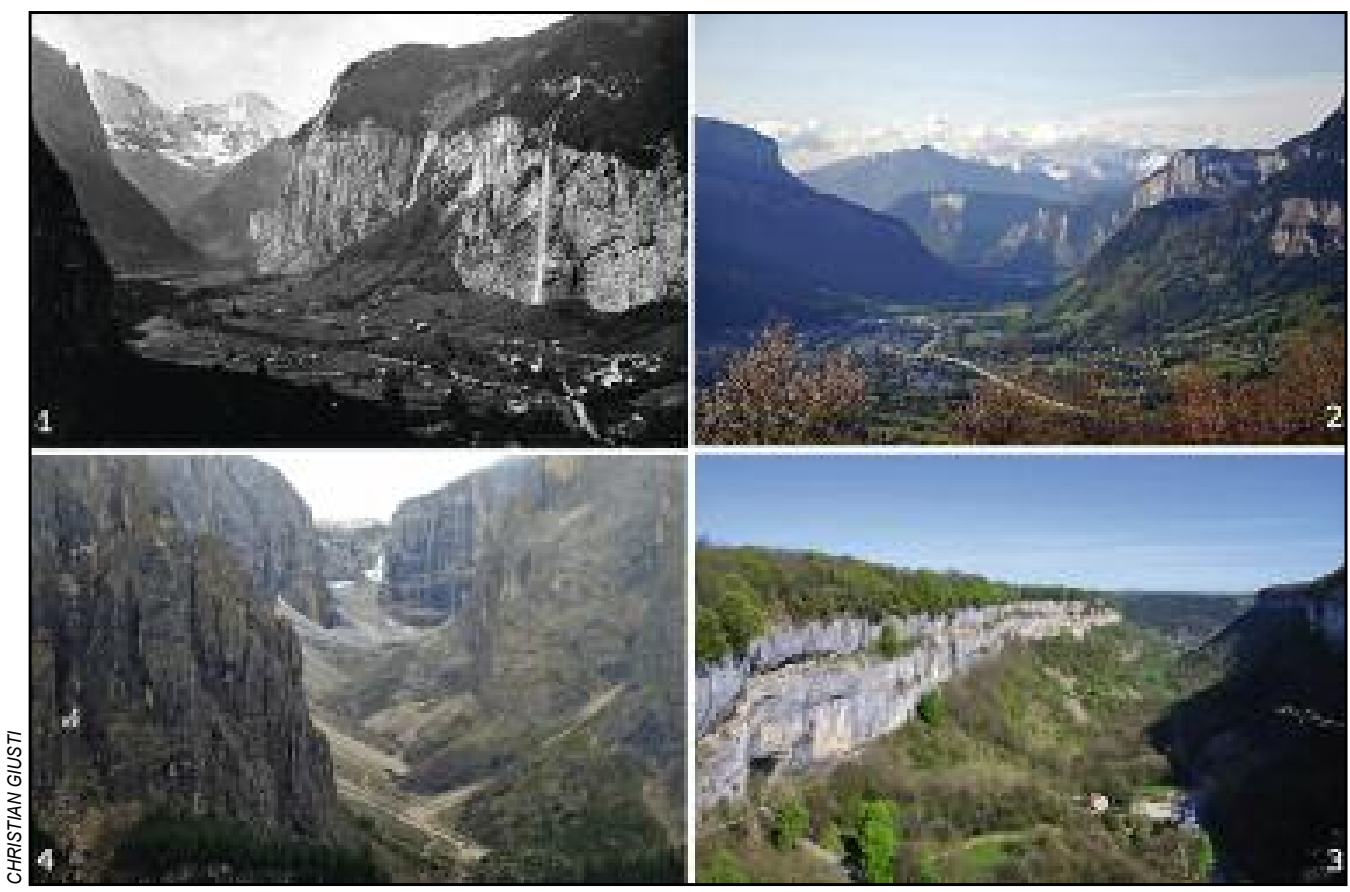

Figure 1: Alternative possible landscapes for Tolkien's Rivendell in Middle-earth, from top left, clockwise: 1) the Lauterbrunnen Valley nearly a century ago by Giorgio Sommer (Lauterbrunnen ... 2014); 2) the Arve Valley north of Sallanches, 2008; 3) the blind valley of Baume-les-Messieurs, 2014; 4) the Mesdi Valley, 2009). 


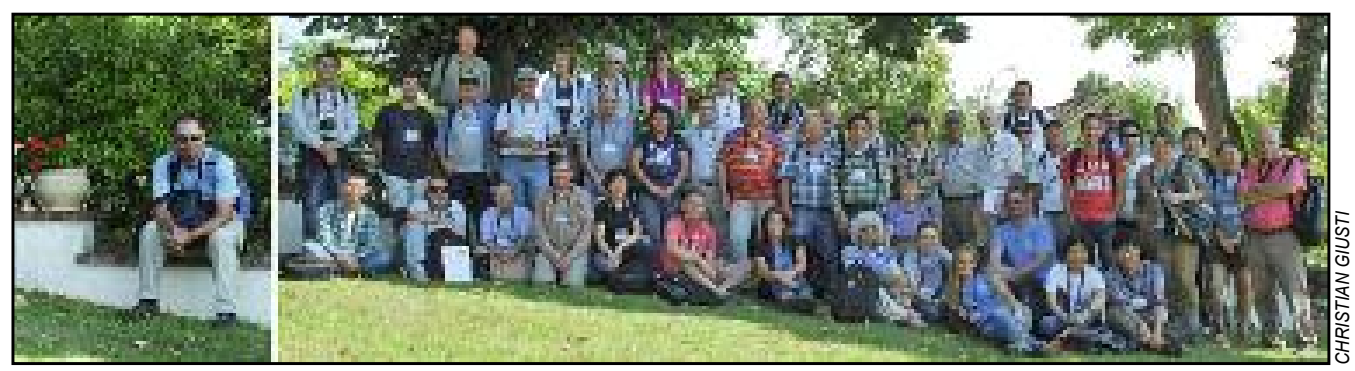

Figure 2: Bojan Erhartic in Giverny, August 29th, 2013. In the group photo, Bojan stands in the last row, second from right (blue T-shirt), near Emmanuel Reynard.

The following pages are dedicated to the memory of Bojan in two parts. The first part is devoted to some general ideas (such as those that Bilbo Baggins, had he been a geomorphologist, would have had in Elrond's house after a long journey), and the second part deals with a bit of geology, landscape features, and karst surficial landforms of various Paleozoic limestones in the Black Mountains (Montagne Noire) of southern France.

\section{The Black Mountains: „There and back again"}

In metropolitan France, the southern Massif Central is the contrasted area that lies between Toulouse in the west and Montpellier southward, straddling the two administrative regions of Midi-Pyrénées and Languedoc-Roussillon, to be merged as one of the fourteen new super-regions after the territorial reform law passed by the National Assembly in July 2014. Regarding landform development, the main property of the country is that of a large plateau, itself part of a larger unit formerly known as Franc's Massif Central (Baulig 1928; Martonne 1942), where most of the rivers flow through deeply entrenched valleys, sometimes taking the appearance of gorges like the Tarn both upstream from Millau and immediately west of the city, where the stunning viaduct designed by the architect Norman Foster stands. Sometimes a hilly landscape with a higher elevation locally looks out over the plateau, as in the Palanges Massif and Lévezou Mountains (Fr. Monts du Lévezou) west of Millau (Aveyron), in the Lacaune Mountains (Fr. Monts de Lacaune) east of Castres (Tarn), in the Espinouse Mountains northwest of Béziers (Hérault) or in the Black Mountains north of Carcassonne (Aude). In fact, the highest summits are, the well-named Montgrand (literally, 'big mountain', 1,269 m) south of Lacaune (at 1,270 m, Mount Rascas, Fr. Puech de Rascas) is a manmade platform built for military use nearby), followed by Nore Peak (Fr. Pic de Nore, 1,211 m), an asymmetric mid-size mountain with round features between Castres and Carcassonne. In the eastern part of the Lacaune Mountains south of Sylvanès Abbey, a particularly picturesque landscape of ridges and valleys despite the presence of increasingly more wind turbines impacting the scenery, a few summits stand near 1,100 meters such as Merdelou (1,110 m) and Croix de Marcou (1,093 m).

The geologists Dufrénoy and Élie de Beaumont (1841), who created the first geological map of France, extended the compound name of the Black Mountains (Montagne Noire) to all the pre-Jurassic areas of the southern Massif Central, including granites, migmatized gneiss and mica-schist, as well as sedimentary formations of Lower Palaeozoic age and low metamorphic grade. This is explained by Jules Bergeron (1887), the creator of the first detailed 1:80,000 geological map:

Le massif montagneux qui sétend de Castelnaudary à Lodève porte les différents noms de montagne Noire, d'Espinouse, de Saumail et de Caroux; mais il présente, au point de vue de sa constitution géologique, une unité telle qu'on ne peut y faire les distinctions admises en géographie, et l'on est en droit de le désigner tout entier sous le nom de Montagne Noire, qui est celui de la plus grande chaîne" (The mountain range that extends from Castelnaudary to Lodève bears the various names of the Black Mountains, Espinouse Mountains, Saumail Mountains, and Caroux Mountains, but from the point of view of its geological formation it represents a unit such that we cannot make distinctions on a geographical basis, and it is appropriate to designate all of it as the Black Mountains, which is its largest chain.) 
Despite the reservations expressed by the geomorphologist Henri Baulig (Beckinsale and Chorley 1991; Derruau 1999), and that geographers disagree with the excessive extension geologists give the name of the Black Mountains when they apply it to the entire southwest part of the Massif Central, including the Agout Plateau, the Lacaune Mountains, and the Southern Segala (Baulig 1928), this use has persisted to today (Thoral 1935; Gèze 1949; Arthaud 1970; Faure et al. 2009). Therefore, the term Black Mountains is used in a broad sense at the regional scale for a geological massif comprised of an Axial Zone sandwiched between the Northern Side and the Southern Side (Figure 3), and in a narrow sense the Black Mountains is the term used at the local scale for the geographical tract of land that overlooks the Thore Valley in the vicinity of Mazamet (Figure 4).

With regard to the geological literature, the publication of the Castres sheet in 2013 completed the publication of the detailed 1:50,000 geological map, which began in the early 1970s, and which is summarized by the $1: 250,000$ Montpellier sheet (Berger et al. 2001; Alabouvette et al. 2003). Concerning the pre-Permian basement, Demange $(1975,1998,1999)$ sought to find the model proposed in the Eastern Pyrenees by Fonteilles and Guitard (1977) in the Black Mountains. However, the Ordovician age (Roger et al. 2004; Cocherie et al. 2005) of orthogneiss of the Axial Zone has since invalidated the hypothesis of several "Precambrian orthogneissic cores « involved in thrust nappes of Penninic style (Laumonier et al. 2004; Charles et al. 2009; Roger et al. 2015). Consequently, recent works (e.g., Faure et al. 2009, 2010) prefer to go back to former structural maps such as those published by François Arthaud (1970) or even by Bernard Gèze (1949).

With regard to the geomorphological literature, since the pioneering essay by Abbé Jean-Louis Giraud-Soulavie in 1781 (Baulig 1928; Chorley et al. 1964), numerous works concerning the southern Massif Central have been devoted to the development of its landforms, with special emphasis on the strong contrast between remnants of paleoplains in the sense of Ollier (1991) and deeply incised valleys (Giusti 2002), as exemplified by the emblematic Espinouse-Caroux Plateau overlooking the Orb-Jaur Valley (Figure 5). Obviously, the explanation of landforms such as paleoplains deals with long-term geomorphology; that is, »the study of landforms that are of mostly pre-Quaternary, Cenozoic, Mesozoic or even Palaeozoic age, ... with the lowering of a land surface to the base level (mostly sea level), leaving a new land surface (Ebert 2009). There is a long history of long-term geomorphological studies in the southern Massif Central, which, on the one hand, offers any geoscientist (geographer, geologist, or geomorphologist) a large amount of significant data and observations but, on the other hand, adds to the difficulty because the proposed interpretations are not of equivalent value and often contradict one another. Moreover, for works published before 1980, there is also the difficulty of correspondence between current science and the former scientific framework. To take just one example, the definitions of the Miocene, Pliocene, and Quaternary have changed substantially since Baulig's thesis in 1928 about the effects of Neogene eustatic variations throughout the Mediterranean basin (Beckinsale and Chorley 1991; Klein 1999), and so any citation of older publications have to be carefully contextualized. However, any work, regardless of the date of publication, refers to local observations (paleontological sites, geological outcrops, sections of soils, and geomorphological point of views) that may still have some value as long as they have been carefully checked (including in the field, if this is even possible) and interpreted according to scientific criteria and standards currently in use. However, another point must be now emphasized, which is the scope of the conclusions in relation to the size of the area studied. The most frequent situation is that of local studies attempting to generalize their findings to the southern Massif Central as a whole. This would be justified if the bedrock (solid) were of homogeneous composition and structure, which is not the case at all. This approach systematically leads to inconsistencies because local results are difficult to generalize to all of the southern Massif Central. Even a careful study such as the one by Ambert (1994), focusing on a transect from Millau (Causses, Aveyron) in the north to Montpellier (Bas-Languedoc, Hérault) in the south, leads to conclusions that are not really convincing at the regional scale. Incidentally, over-specialization is another limitation; for example, when karst specialists consider it unnecessary to study the nearby crystalline massifs, or, conversely, when bedrock specialists set aside the Causses geomorphology. However, at a larger regional scale, both morphostructural units function as open systems and sub-systems involved in a common history they share geomorphologically speaking. This is precisely what makes the works by Baulig (1928) and Le Griel (1988) interesting: these two major works, sixty years apart, integrated the regional scale into an overall analysis of the Massif Central and its neighboring regions (Giusti 2002, 2012). 


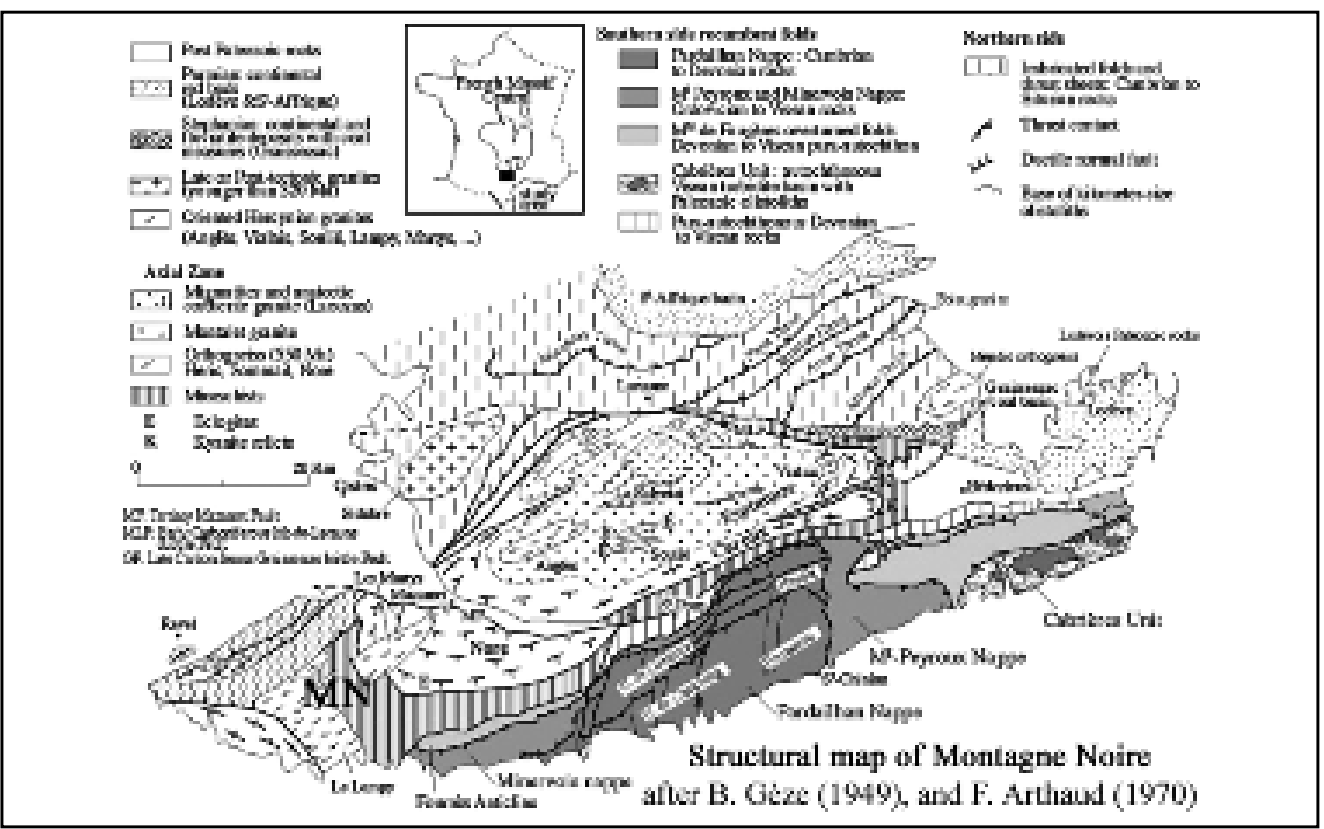

Figure 3: The Black Mountains in the broad sense as a geological massif (Faure etal. 2010: 656), modified to show the emplacement of the Black Mountains in Figure 4.

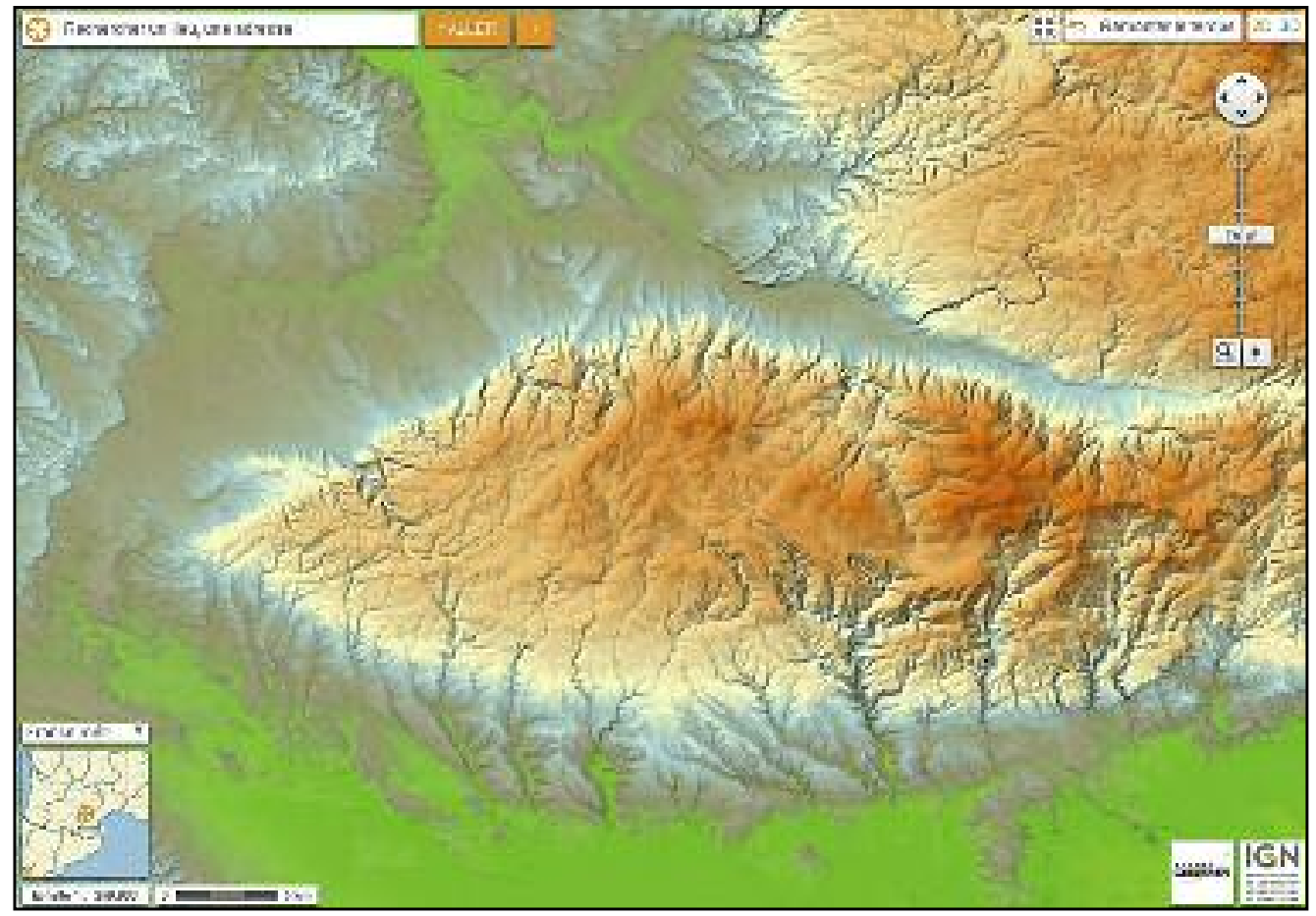

Figure 4: The Black Mountains in the narrow sense as a geographical massif (DEM from IGN, Géoportail ... 2014). 


\section{Palaeozoic limestones in the Black Mountains: from outcrop to landscape, extensive geodiversity}

In the impressive karst study Grottes et Karsts de France (Caves and Karst in France, Audra 2010), thirteen references are devoted to the karst phenomena and landscapes of the garrigues, Grands Causses Plateaus, and Black Mountains, with an interesting text about karst systems of the Minervois (Bès 2010) in the southwest part of the Southern Side (Figure 3). Unfortunately, nothing is said about the geo(morpho)logy of other calcareous outcrops of the mountains of Pardailhan, Faugères, or Cabrières (also on the Southern Side) or, moreover, about the small limestone plateaus (Fr. causses) linked to the large outcrops of Cambrian limestones on the Northern Side of the Black Mountains, mainly in the areas of Marcou and Mélagues (Aveyron), or in Dourgne and Sorèze near Revel (Tarn; e.g., Gazelle 1979; Favory and Gazelle 1982). In the Black Mountains considered as a geological massif (Figure 3), carbonate sedimentary rocks such as limestones or dolomites are well represented in the lower part of the Cambrian system, in all of the Devonian system, and in places in the Lower Carboniferous sub-system (Tournaisian). It must be pointed out that Carboniferous marine sedimentary deposits of the "Klippen of Cabrières « unit are known of many geologists worldwide due to the presence of a Global Boundary Stratotype Section and Point (GSSP) located at the "La Serre« section, where the base of the Carboniferous System, Mississippian Sub-System, and Tournaisian Stage are defined (Gray 2013; GSSP for Tournaisian ... 2014). Two other GSSPs are located nearby: the Coumiac Quarry (Figure 6), the base of the Famennian Stage (GSSP for Famennian ... 2014) and the Mount Suque Pass (Fr. Col du Puech de la Suque), the base of the Frasnian Stage and Upper Devonian Sub-System (GSSP for Frasnian ... 2014).

The second edition of Gray's textbook (2013) proposes a new and more comprehensive definition of "geodiversity « as »the natural range (diversity) of geological (rocks, minerals, fossils), geomorphological (landforms, topography, physical processes), soil and hydrological features. It includes their assemblages,

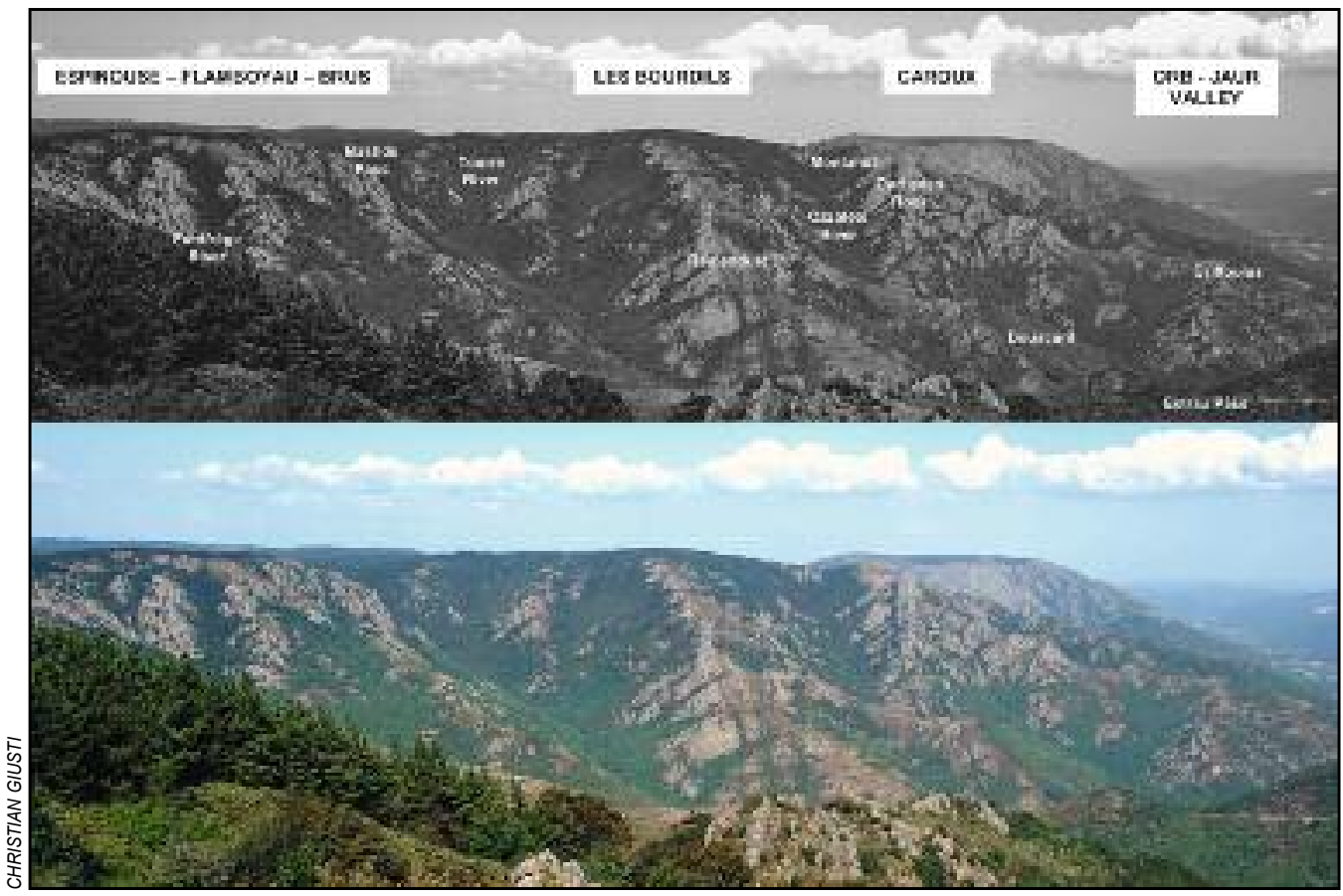

Figure 5: The Espinouse-Caroux Plateau seen from Somail, looking eastward, 2009. Note the contrast between the faint sub-horizontal relief of the highland plateau and the strong sub-vertical southward dip of the Axial Zone gneisses (as exemplified in Ramandure, Montahut, and the Ourliades Rocks). 


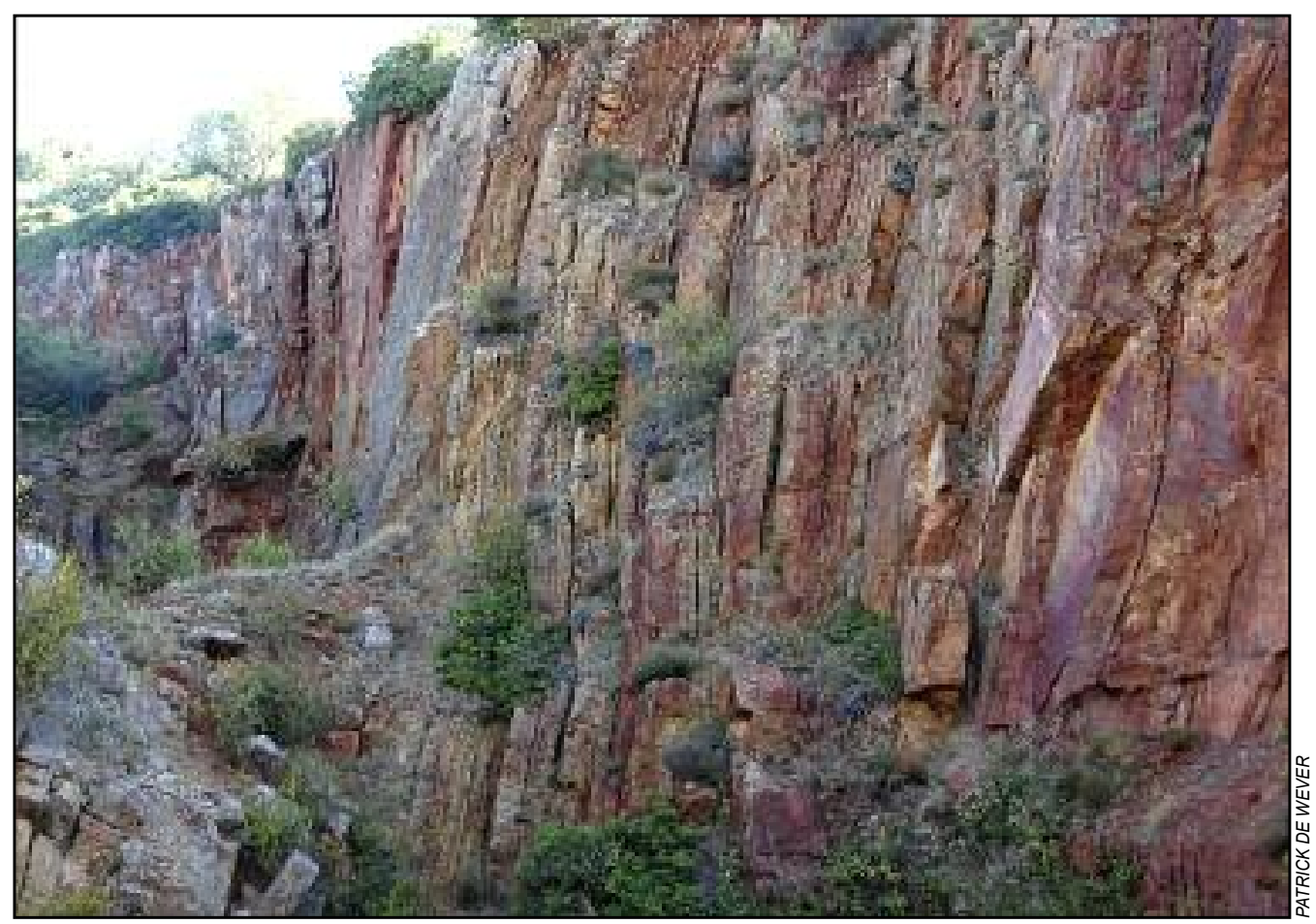

Figure 6: The Upper Coumiac Quarry, near Cessenon-sur-Orb (Hérault), 2006. Pelagic calcilutites, mostly red tinted and well-bedded. The GSSP between the Frasnian and Famennian Stages (Devonian) is adjacent to the southeastern border of the quarry that was mined for a red nodular limestone exported all over the world (e.g., for the White House in Washington, or the French tourism office (Fr. Maison de la France) in Rio de Janeiro). This series corresponds to the Famennian Biological Crisis responsible for one of the most severe mass extinctions in Earth's history.

structures, systems and contributions to landscape." The second part of this helpful definition confirms the belief that it is appropriate to use the nested concepts of geotope, geofacies, and geosystem as defined nearly half a century ago by the geographer Toulouse Bertrand (1968), which can easily be applied to geomorphological objects and processes that affect them (Giusti et al. 2010; Giusti et al. 2013).

\subsection{At the scale of a single outcrop: the geotope}

Of course, it would be quite easy to start this section with some famous examples of quarries of ornamental stones, such as those of Caunes-Minervois north of Carcassonne, which provided the red marble of Languedoc used for the Grand Trianon (or »Marble Trianon«) in Versailles (Gèze 1979; Lorenz and Féraud 2004), or the Marbres de France quarries near Saint-Pons-de-Thomières (Marbres ... 2014). However, it is more interesting here to mention three outcrops of rather small extension, but that are interesting pieces of great significance though still poorly connected (at least two of them) into the geological jigsaw puzzle of the Black Mountains as part of the patchwork of the Variscan belt (Faure et al. 2009, 2010).

\subsubsection{The diverse values of the Le Bessou geotope}

From Saint-Gervais-sur-Mare (Hérault), Road D 922 rises towards Lacaune (Tarn), crossing the pass at La Croix de Mounis $(808 \mathrm{~m})$. In the climb, about $1.5 \mathrm{~km}$ past Le Péras near the locality of Le Bessou, the section of the road exhibits a coarse conglomeratic outcrop of Upper Carboniferous age (Stephanian, h5 on the 1:50,000 geological map) that lies unconformably on a light grey massive dolostone formation of Lower Cambrian age (k2 on the 1:50,000 geological map), formerly known as »Calcaires à Archéocyathes« (Figure 7, 


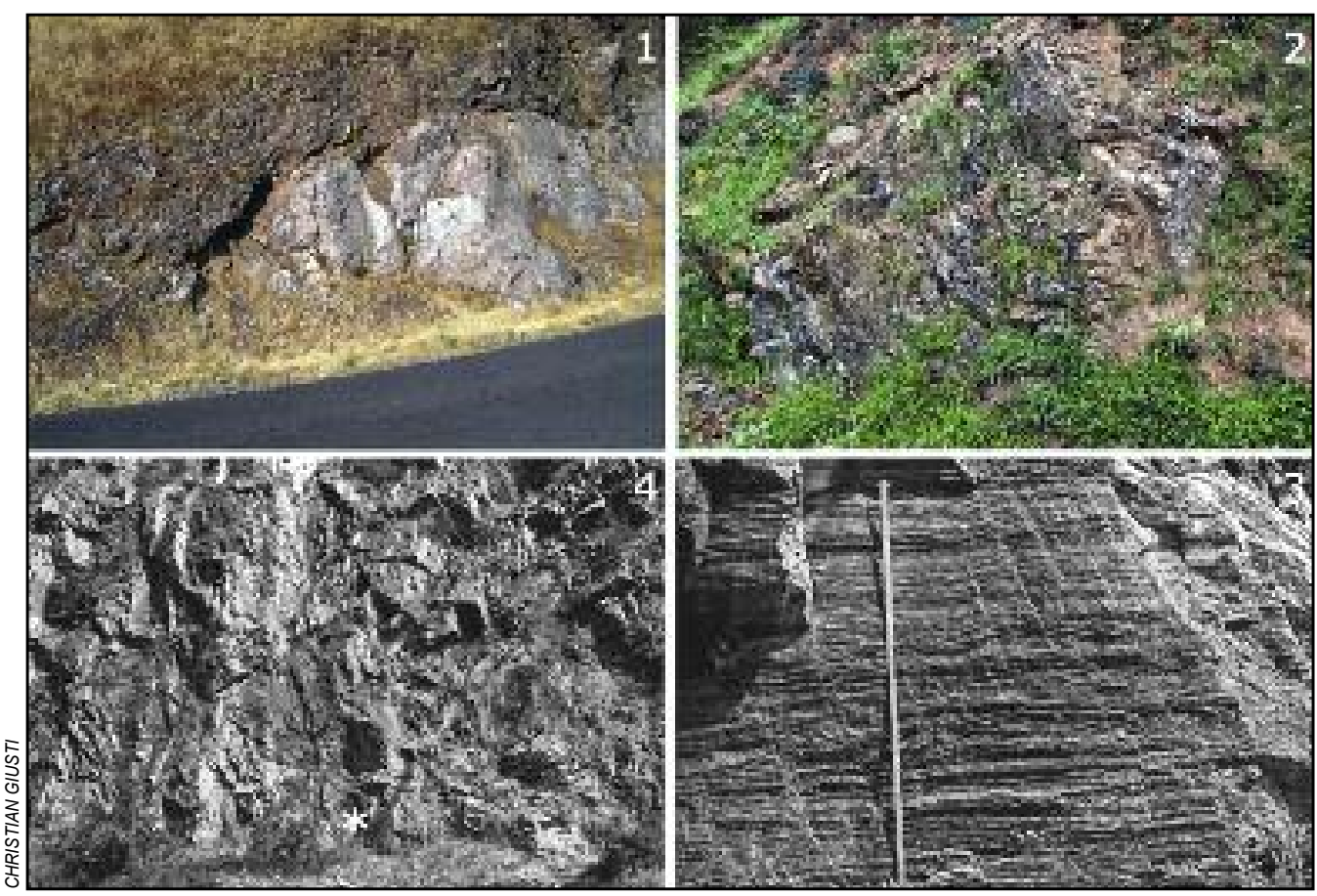

Figure 7: Some interesting geotopes in the Black Mountains. From top left, clockwise: 1) Stephanian conglomerates of the Graissessac Basin lying unconformably on the Lower Cambrian dolostones of the Mélagues Unit near Le Bessou, west of Saint-Gervais-sur-Mare (Hérault), 2003; 2) Silurian Orthoceras limestones of the Murasson Unit near Mas de Barthès, southwest of Camarès (Aveyron), 2011; 3-4) Dolomite (Proterozoic? Cambrian? Devonian?) of the eastern Axial Zone near La Billière, north of Lamalou-les-Bains (Hérault), 1981, partial view (3, below right, bar scale: $1 \mathrm{~m}$ ) and general view (4, below left, with * showing the position of photo 3 ).

top left). The dark Stephanian conglomerates contains numerous heterometric fragments of sandstones (Lower Cambrian, k1 on the 1:50,000 geological map) and dolostones (Lower Cambrian, k2). Therefore, the geotope of Le Bessou has a dual heritage value, first as a site of geological interest (geosite) and second as a site of geomorphological interest (geomorphosite). Like anywhere else in the Massif Central, the local Stephanian deposits are part of an intramontane coal basin (Graissessac) that is coeval with a D5 event associated with a late orogenic extensional tectonic regime accommodated by NNE-SSW stretching (Faure et al. 2009). Concerning the block of Cambrian limestone $\mathrm{k} 2$, it could be an autochthonous outcrop, but it has also been interpreted more likely as an olistolith fallen in the intramontane basin during the Late Carboniferous sedimentation (Becq-Giraudon 1984): from the geomorphological perspective, the carbonate formation $\mathrm{k} 2$ of Lower Cambrian age was not karstified much before fossilization by the deposits of the Upper Carboniferous, as a careful examination of the unconformable local contact reveals. The other value of this geotope is to provide an excellent view of the Orque Cliff (Fr. Falaise d'Orque) with the Marcou Mountains (Fr. Montagne de Marcou) in the distance (Figure 10), so it can be defined as a geospot because the outcrop here is coupled with a major view of panorama-type (Giusti et al. 2013).

\subsubsection{The paleogeographic value of the Mas de Barthès geotope}

A long and winding road provides access in the twenty kilometers from Camarès (Aveyron) to Lacaune (Tarn), passing through the Bataillole Pass (Fr. Pas de la Bataillole). Just west of the pass, facing Mas de Barthès, the section of the road exhibits an outcrop of Silurian limestones (Figure 7, top right), which connects with the large Silurian area of Murasson (Aveyron), known since the end of the nineteenth century (Bergeron 1883). Thereafter, a detailed geological survey of the local Silurian was carried out by Marcel 
Thoral (1935), whose work was subsequently clarified by André Centène $(1975,1977)$ through the study of Conodonts, and by Jean-Pierre Prian (1980) for lithostratigraphy and geological mapping (the boutonnières of Le Cros, Laime's river, and the Rance Valley west and north of Mounes). It must be recalled that the Silurian of Murasson (NS of the Black Mountains) is very different from that of the Laurens-Cabrières area on the Southern Side (Chaubet 1937), a fact not really astonishing given the great complexity of the western peri-Gondwana margin paleogeography (see the position of the Maures-Black Mountains block on the reconstructions by Stampfli et al. 2013) and the intensity of tectonics in the outer zone of the Variscan Belt (Faure et al. 2014).

\subsubsection{The enigmatic value of the La Billière and Castanet-le-Haut geotopes}

More or less thick layers of limestone or dolomite may be interspersed throughout the mass of azoic metamorphic schists of low grade known as Schistes X, which envelop the magmatic and high-grade metamorphic
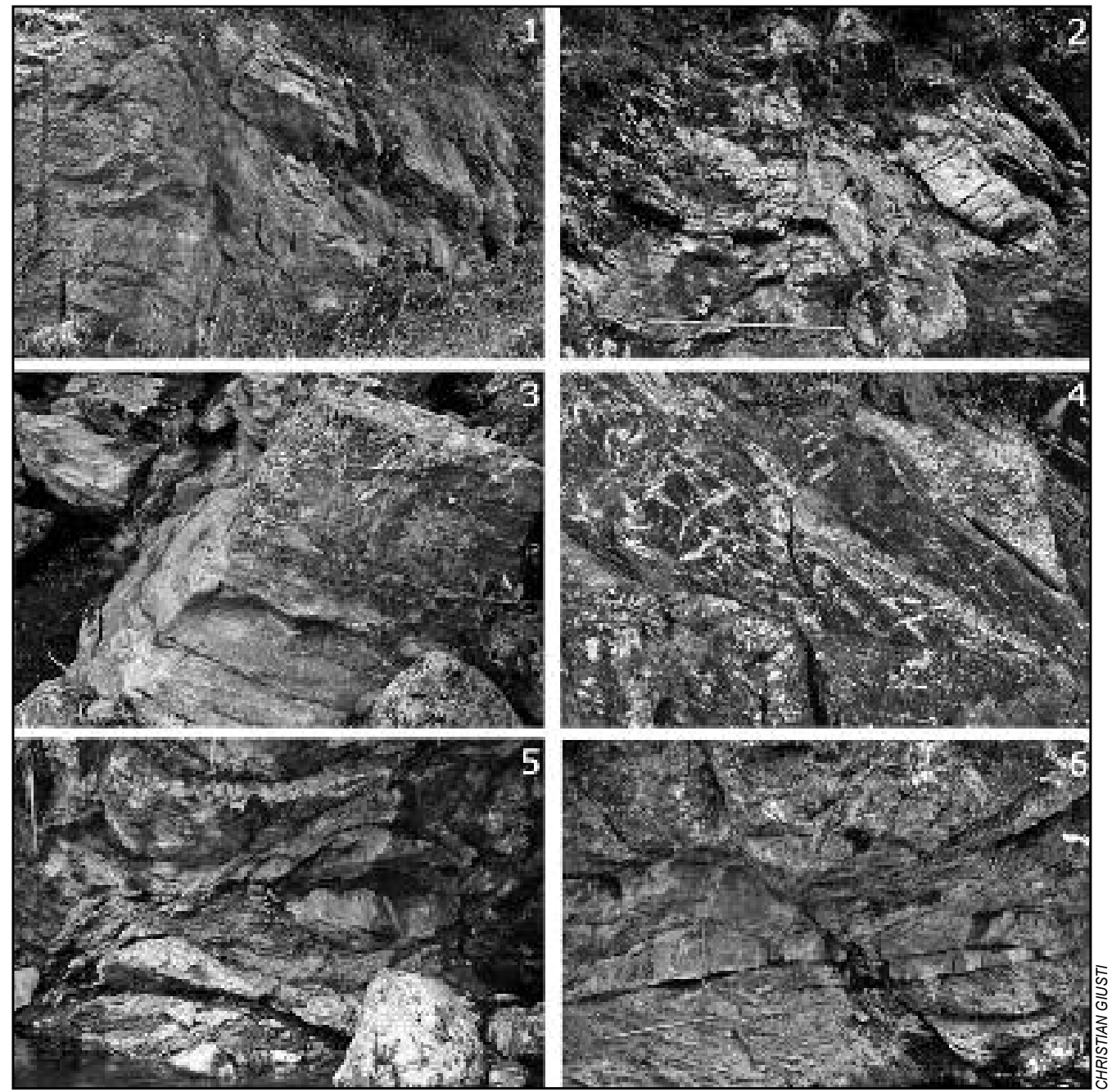

Figure 8: A disconnected geosite: limestone outcrops of the Upper Mare Valley near (astanet-le-Haut (Hérault). 1) At the entrance of the village, along

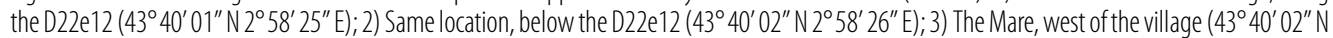
$\left.2^{\circ} 58^{\prime} 07^{\prime \prime} \mathrm{E}\right)$; 4) On the road to Pabo, D22e11, east of the village ( $\left.43^{\circ} 40^{\prime} 05^{\prime \prime} \mathrm{N} 2^{\circ} 58^{\prime} 54^{\prime \prime} \mathrm{E}\right)$; 5) In the village, along (apials (reek ( $\left.43^{\circ} 40^{\prime} 07^{\prime \prime} \mathrm{N} 2^{\circ} 58^{\prime} 18^{\prime \prime} \mathrm{E}\right)$; west of the village, along the Mare $\left(43^{\circ} 40^{\prime} 10^{\prime \prime} \mathrm{N} 2^{\circ} 57^{\prime} 40^{\prime \prime} \mathrm{E}\right)$. All photos were taken in 1982. 
rocks (granites, migmatites, gneiss, micaschists, etc.) that form the Axial Zone. One of the most notable examples is situated in the Saint-Gervais Mountains (Fr. Monts de Saint-Gervais) area north of Lamalou-les-Bains (Hérault, 34), in an abandoned quarry near La Billière (Figure 7, below). The local Schistes X series was first divided into three main groups X1, X2, and X3 (Ellenberger and Latouche 1967), in the third edition of the $1: 80,000$ Bédarieux geologic map (Gèze 1971), then in nine formations numbered $\mathrm{x}_{3}$ to $\mathrm{x}_{11}$ (Ellenberger and Santarelli 1974) on the new 1:50,000 Bédarieux geologic map (Bogdanoff et al. 1984). On the former, the La Billière dolomite is noted $\mathrm{X}_{\mathrm{C}}^{2}$, and it appears on the latter as a strata included in the $\mathrm{x}_{9}$ formation, labeled Schistes $d u$ Barry). However, the lithostratigraphic continuity of the "Schistes $\mathrm{X}$ « as a single monocline was later challenged by Michel Demange, who divides it into four superposed independent tectonic units (the autochthonous Axial Zone, the discontinuous Madalèze unit of epimetamorphic grade, the Cabausse unit of andalusite-staurolite grade, and the Haute-Mare unit of low-grade metamorphism) separated by mylonitic thrust planes (Demange and Herrera Urbina 1989). Because the limestones of Devonian age are generally quite rich in fossils (crinoids), it is possible and even likely that the La Billière geotope corresponds to a tectonic unit (klippe) of Cambrian dolomites (Berger et al. 2001). However, an older age (Upper Proterozoic?) cannot be excluded (Gèze 1949), especially because the Cambrian of the Avene unit could be quite older than that of the Mélagues unit (Devaere et al. 2014), just north of the Upper Carboniferous Graissessac Basin.

Even more puzzling are several tiny outcrops of calcareous formations to be observed here and there in the Upper Mare Valley, mainly around Castanet-le-Haut (Hérault, 34), between the Axial Zone and the southern limit of the Upper Carboniferous Graissessac Basin (Figure 8). Some are included in the "Schistes X (Figures 8.1 to 8.4), and others are only fragments pinched in the schists just at the base of the blaviérites (rhyolitic tuffs and breccias), a formation of volcanic origin with strong deformation (Figures 8.5 and 8.6). These outcrops are very difficult to date and to interpret because, in addition to the absence of fossils, they are all situated along a steep north-dipping fault zone, with successive intervention of folding and thrusting of southward tectonic vergence, a dextral shear zone, and vertical uplift (e.g. Demange 1993; Malavieille 2010).

\subsection{At the scale of a group of outcrops: the geofacies}

To illustrate a single outcrop (geotope), one photo is generally enough, perhaps two if a close-up is required (e.g., Figures 7.3 and 7.4). In contrast, for a group of outcrops, it is necessary to offer at least a pair of twinned pictures, sometimes more, with a large panoramic view and part of it as an example in the case of a very homogeneous geofacies. If, as frequently happens, the geofacies is heterogeneous, the panoramic view has to be supplemented by pictures as detailed as required. Both situations are exemplified by a comparison of two sites.

\subsubsection{A heterogeneous geofacies: the Roque Redonde olistolith}

The Cabrières Unit is currently interpreted as an olistostrome about 20 kilometers long from Laurens in the west to Villeneuvette in the east, well exposed at the southeastern part of the Devonian to Visean overturned folds of the Faugères Mountains (Fr. Monts de Faugères) para-autochthonous area (Faure et al. 2010). This very complex unit, first described and mapped by Jules Bergeron (1899) and Bernard Gèze (1949), exhibits large-scale olistoliths of Carboniferous and Devonian limestones, Silurian volcanites and Ordovician turbidites, forming a wildflysch sequence deposited during the Visean and Early Namurian stages at the front of the advancing nappes of the Southern Side (Engel et al. 1978, 1980; Feist and Galtier 1984). On the geologic map (Figure 9, top left), the Visean wildflysch corresponds to two very distinct lithological facies because huge blocks of shallow-water limestones formerly known as Productus giganteus reefs (Fr. récifs à Productus giganteus; h2b, purple-grey) are packed in a thick formation mainly composed of silty shales and greywacke-turbidites (h2b, medium grey). The reef limestone olistoliths are more or less hidden by a sparse oak coppice, as shown by the rocky hills of Roque de Castel Viel (sparsely wooded) and Roque de Loup (more wooded; Figure 9, top right). Most often, outcrops of light gray limestone are highly visible and clearly identifiable in the landscape as for the mountain Roc Murviel (Figure 9, bottom left), where rain seeps through the Visean limestone so that only lean soils and sparse vegetation may develop. The ovoid mountain Roque Redonde (Figure 9, bottom right) is a small asymmetric massif that emerges from the thick mass of the flysch and rising about a hundred meters above the floor of the Peyne Valley, which 
was probably cut just after the shaping of many partial erosion planes at the end of the Neogene Period (Giusti 2002). Although the weak material of the wildflysch is frequently truncated by an erosion surface known as a glacis d'érosion bearing vineyards today, the adjacent uplands are often made of limestone with a local relief of 100 to 150 meters. During the Proto-Historic Period, those hills could be easily defended: this is why ancient habitats of the Bronze Age and Iron Age might be found here and there on the top (Bagan and Beugnon 2014).

\subsubsection{A homogeneous geofacies: the Roc d'Orque escarpment}

A heterogeneous geofacies leads back to outcrops and multiple geotopes because of the constant modifications of geological features of the topography, and so it is possible to show that, conversely, a homogeneous geofacies leads to the landscape dimension. In the author's opinion, the geotope of Le Bessou (Figure 7.1) should also be named a "geospot « because, looking towards the northeast, one can observe a panoramic view whose main feature is an escarpment 50 to 100 meters high (Figure 10, top), culminating at the hill Roc d'Orque (Figure 10, bottom left). According to the geologic map and recent works (Bogdanoff et al. 1984; Devaere et al. 2013, 2014), the escarpment is made up of a solid dolomitic package ( $k 2$ ) referred to the Lastours Formation (Minervois Nappe, Southern Side) conformably lying on a siliciclastic group (k1) correlated with the Marcory Formation (Pardailhan Nappe, Southern Side; Figure 3). The upper part of the siliciclastic group (k1) contains carbonate beds and lenses cropping out along the base of the dolomitic cliff (k2), with a faunal assemblage that suggests that these beds may be a lateral equivalent of the mixed (carbonate-siliciclastic) Pardailhan Formation of the Southern Side (Devaere et al. 2013, 2014). Both Lower Cambrian sedimentary layers form the Le Fau-Albes syncline (Figure 10, middle), so that the homogeneous geofacies nearly two kilometers long on the left bank of the Orque Valley is made up of a dolomitic

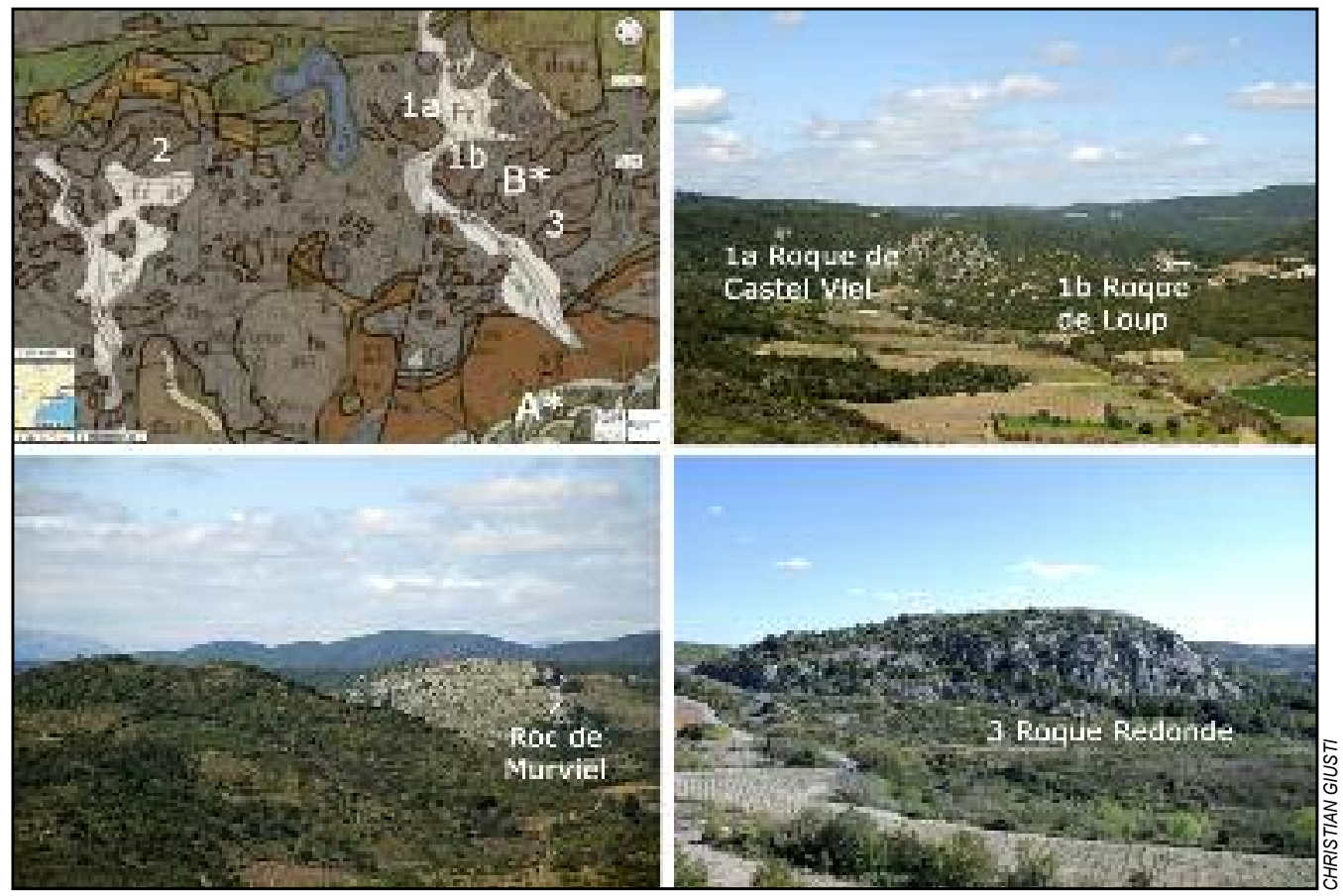

Figure 9: Geofacies of the Visean wildflysch near Vailhan (Hérault). 1:15,000 geologic map (top left, from the 1:50,000 Pézenas geologic map; Berger et al. 1981) showing the emplacement of the hill Roque de Castel Viel (1a, $235 \mathrm{~m}$ ) and the hill Roque de Loup (1b, $206 \mathrm{~m}$; top right), then the mountain Roc de Murviel (2,286 m; bottom left), both seen from the top of the hill Grand Glauzy $\left(229 \mathrm{~m}, \mathrm{~A}^{*}\right)$, and of the mountain Roque Redonde $\left(3,203 \mathrm{~m}\right.$; bottom right) southward from Vailhan (point $\left.178 \mathrm{~m}, \mathrm{~B}^{*}\right)$. Note that local relief is less than 150 meters. All photos were taken in 2008. 
escarpment in its upper part and a siliciclastic slope in its lower part (Figure 10, bottom left), both corresponding to the normal limb of an asymmetric syncline. The deepening of the lower part of the Orque Valley postdate the formation (probably at the end of the Neogene Period) of several partial planes of erosion (Giusti 2002), here represented by Le Péras strath terraces (a, b, and c, Figure 10, bottom right). In the end it must be pointed out that the Orque Valley is not a symmetrical one because the right slope is very different from the left slope, where the Roc d'Orque dolomitic pillar (geotope) and escarpment (geofacies) are part of a larger geosystem as a whole.

\subsection{At the scale of a landscape: the geosystem}

The dolomitic heart of the Le Fau-Albès syncline is an unsung paradise for karst studies (e.g., Albès Cave), as well as for fans of canyoning (e.g., Albès Canyon). If, instead of examining landforms from one or two

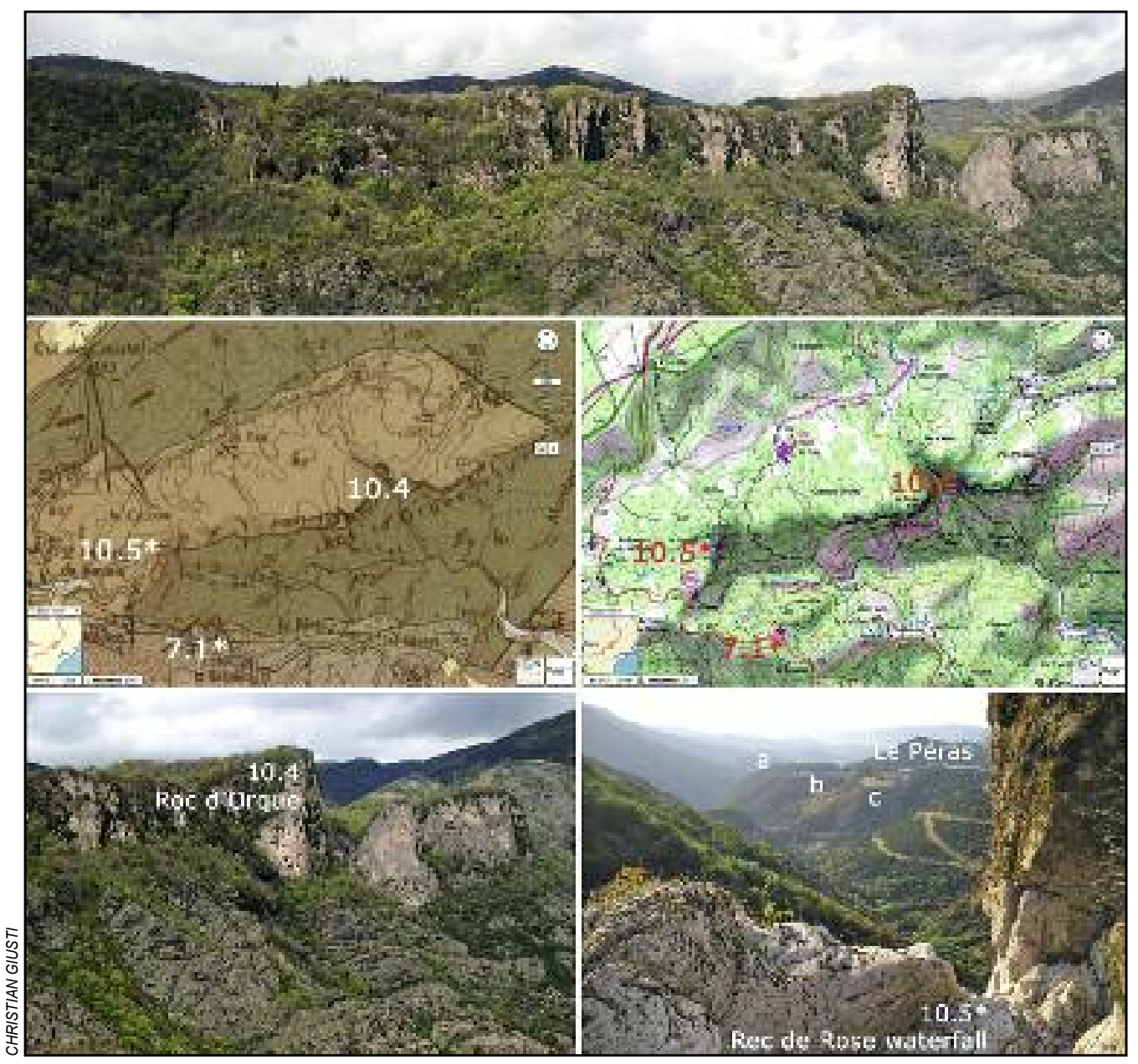

Figure 10: Geofacies of the Lower Cambrian k1-k2 of the Le Fau-Albès syncline in the Mélagues Unit, west of Saint-Geniès-de-Varensal (Hérault). Below the panoramic view (top) taken from the Le Bessou geotope (Figure 7.1), 1:15,000 geologic map (center left, from the 1:50,000 Bédarieux geologic map; Bogdanoff etal. 1984) and topographic map (center right) at the same scale showing the emplacement of the hill Roc d'Orque $(10.4,846 \mathrm{~m}$; below left) and Rec de Rose Falls (10.5*, dry during summer) with the right slope of the Orque Valley near Le Péras. All photos were taken in 2009, except lower right, 2003. 


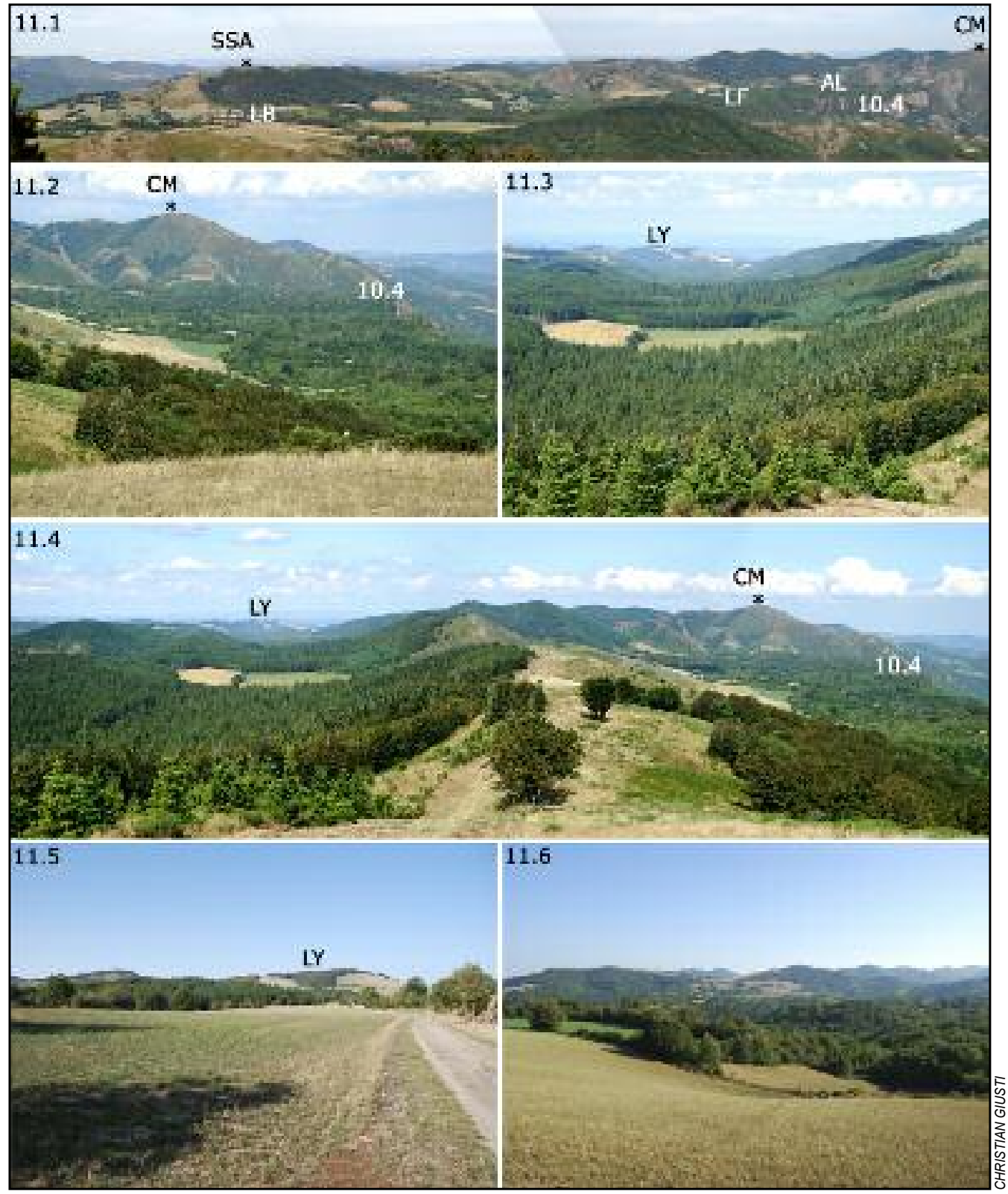

Figure 11: Geosystem of the Marcou Mountains (Fr. Monts de Marcou) in the Mélagues Unit (Eastern Monts de Lacaune Mountains, Aveyron and Hérault). CM: Croix de Marcou. LY: Liaury. SSA: Signal de Saint-Amans. AL: Albès. LB: La Baraquette. LF: Le Fau. 11.1: Panoramic view from the Espinouse (2009), and showing the entire extension of the dolomitic heart (k2) of the Le Fau-Albès syncline from La Baraquette in the west. Rounded summits such as the Signal de Saint-Amans (SSA* 1,008 $\mathrm{m}$ ) or the Croix de Marcou (CM*1,093 m) are associated with the siliciclastic formation ( $\mathrm{k} 1)$, which forms ridges rising 150 to 250 meters above the local relief of elongated and subhorizontal troughs related to the dolomitic formation ( $k 2$ ). 11.2 and 11.3: Separate views of the geofacies of Causse d'Albès (left) and Causse de Saint-Pierre-des-Cats with Liaury in the distance (right), both pictures were taken from the SSA (2009). 11.4: Also from SSA (2009), a panoramic view showing the geosystem of linear valleys associated with the dolostones (k2) of Le Fau-Albès syncline and Saint-Pierre-des-Cats monocline, and intervening round ridges related to the sandstones (k1) of the Mélagues anticline (SSA) and Marcou thrust (CM). 11.5 and 11.6: Separate views of a planar landform in the dolostones south of Liaury (left, taken from Cayourtes) and geofacies of the Albès syncline in the Bobes area (right, taken from Liaury; both in 2007). 
viewpoints only (Figure 10), one coordinates a series of observations from multiple viewpoints forming a network, such as in the case of disconnected geomorphosites proposed by Reynard (2009), it becomes possible to move from the geofacies to the perception of the entire geosystem, as shown in the case study of the Marcou Mountains (Fr. Monts de Marcou; Figure 11). Incidentally, the implementation of such a photo composition requires a good knowledge of the field, acquired after several observation missions and benchmarking. The main summits are associated with Lower Cambrian sandstone (k1). Large karst landforms that are quite frequently more or less flat are reported on the topographic map using the term causse limestone plateau' (Figure 10, center right). They can be observed 150 to 250 meters below the siliciclastic culminating ridges, and are probably related to a phase of local planation that occurred in the highlands during the Neogene (Miocene?). It has been shown that, in the lowlands, those partial planes of erosion are extended by a regional palaeosurface (Giusti 2002). The current landscape is the result of further excavation of the valleys during the Neogene Period and Pleistocene Epoch, although another phase of partial planation with formation of strath terraces could occur at the very end of the Neogene. In short, the Espinouse-Caroux paleoplain is probably a planation surface of regional extension quite well preserved on the magmatic and metamorphic rocks of the Axial Zone (Figure 5), whereas phases of local planation in the Marcou Mountains (Fr. Monts de Marcou) are documented by possible Miocene (Figure 11) and Late Neogene (Figure 10) partial planes of erosion.

\section{Conclusion}

To conclude, this geosystem, which combines the geofacies of dolomitic synclinal valleys on the one hand and the geofacies of sandstone anticlinal ridges on the other, was finely described by the eminent geographer and geomorphologist Henri Baulig $(1928,292)$ nearly a century ago: "Les calcaires, moins résistants, donnent des sillons au sol rouge, avec des buis, de beaux hêtres, du froment, du maïs, des grottes et de fortes sources; les schistes et psammites forment au contraire des crêtes étroites, aux sols minces et grisâtres, portant des châtaigniers, des hêtres rabougris, de maigres cultures de seigle et de sarrazin " (Limestones, which are less resistant, create valleys with red soil with boxwood, beautiful beech trees, wheat, corn, caves and powerful springs; in contrast, shale and psammites create narrow ridges with thin grayish soils supporting chestnut, stunted beech, and meager crops of rye and buckwheat). Today, these crops are in decline, except for corn, there are still herds of sheep, and numerous wind turbines dot the terrain, impacting the landscape. But the Misty Mountains, the River Bruinen, and the Glittering Caves are still there.

\section{The wind's in the treetop, the wind's in the heather; \\ The stars are in blossom, the moon is in flower, And bright are the windows of Night in her tower.}

- J. R. R. Tolkien, The Hobbit

ACKNOWLEDGEMENTS: Thanks to Blaž Komac for his careful editing and thoughtful questions. His contributions have greatly improved the quality of this article.

\section{References}

Alabouvette, B., Demange, M., Guérangé-Lozes, J., Ambert, P. 2003: Notice explicative, Carte géologique de France à 1/250.000, Feuille Montpellier 38. Orléans.

Ambert, P. 1994: Lévolution géomorphologique du Languedoc central depuis le Néogène: grands causses méridionaux - Piémont languedocien. Documents BRGM 231. Orléans.

Arthaud, F. 1970: Étude tectonique et microtectonique comparée de deux domaines hercyniens: les nappes de la Montagne Noire (France) et l'anticlinorium de l'Iglesiente (Sardaigne). Montpellier.

Audra, P. 2010: Grottes et karsts de France. Karstologia Mémoires 19.

Bagan, G., Beugnon, G. 2014: Voyage dans la Protohistoire à travers les vallées de la Boyne et de la Thongue. Los Rocaires 14.

Barnfield, M. 1996: Rivendell in Swizterland. Internet: http://scv.bu.edu/ aarondf/Rivimages/realriv.html (15.9.2014). 
Baulig, H. 1928: Le Plateau Central de la France et sa bordure méditerranéenne. Étude morphologique. Paris.

Beckinsale, R. P., Chorley, R. J. 1991: The history of the study of landforms or The development of geomorphology. Historical and regional geomorphology, 1890-1950. London.

Becq-Giraudon, J.-F. 1984: Graissessac. Carbonifère (S4). Synthèse géologique du Sud-Est de la France. Mémoires BRGM 125, 126. Orléans.

Berger, G., Alabouvette, B., Guérangé-Lozes, J., Demange, M., Ambert, P. 2001: Carte géologique de France à $1 / 250.000$. Feuille Montpellier 38. Orléans.

Berger, G., Feist, R., Freytet, P. 1981: Carte géologique de France à 1/50.000, Feuille Pézenas 1015. Orléans.

Bergeron, J. 1883: Note sur les terrains Silurien et Dévonien de Murasson. Bulletin Société géologique de France 3-12.

Bergeron, J. 1887: Étude géologique de la partie sud-ouest de la Montagne Noire. Bulletin Société géologique de France 3-16.

Bergeron, J. 1899: Étude des terrains paléozoïques et de la tectonique de la Montagne Noire. Bulletin Société géologique de France 3-27.

Bertrand, G. 1968: Paysage et géographie physique globale, esquisse méthodologique. Revue géographique des Pyrénées et du Sud-Ouest 93-3.

Bès, C. 2010: Les karsts du Versant sud de la Montagne Noire. Grottes et karsts de France. Karstologia Mémoires 19.

Bogdanoff, S., Donnot, M., Ellenberger, F. 1984: Carte géologique de France à 1/50.000, Feuille Bédarieux 988. Orléans.

Centène, A. 1975: Graptolites et Conodontes du Silurien des massifs du Midi mediterraneen - Essai de correlation entre les deux echelles. Ph.D., Université des Sciences et Techniques du Languedoc. Montpellier.

Centène, A. 1977: Nouvelles données biostratigraphiques (Conodontes) sur le Silurien des Monts de Lacaune (Montagne Noire, France). Réunion annuelle des Sciences de la Terre 5.

Charles, N., Faure, M., Chen, Y. 2009: The Montagne Noire migmatitic dome emplacement (French Massif Central): new insights from petrofabric and AMS studies. Journal of structural geology 31.

Chaubet, M.-C. 1937: Contribution à létude du Gothlandien du Versant méridional de la Montagne Noire. Montpellier.

Chorley, R. J., Dunn, A. J., Beckinsale, R. P. 1964: The History of the study of landforms or the development of geomorphology. Geomorphology before Davis. London.

Cocherie, A., Baudin, T., Autran, A., Guerrot, C., Fanning, M., Laumonier, B. 2005: U-Pb zircon (ID-TIMS and SHRIMP) evidence for the early Ordovician intrusion of metagranites in the Late Proterozoic Canaveilles Group of the Pyrenees and the Montagne Noire (France), Bulletin Société géologique de France 176.

Demange, M. 1975: Style pennique de la zone axiale de la Montagne Noire entre Saint-Pons et Murat-sur-Vèbre (Massif Central). Bulletin du BRGM 2-1.

Demange, M. 1993: Que signifie la faille des Monts de Lacaune (Montagne Noire, France)? Implications quant au problème de la patrie des nappes. Comptes rendus de l'Académie des Sciences 317-2.

Demange, M. 1998: Contribution au problème de la formation des dômes de la Zone axiale de la Montagne Noire: analyse géométrique des plissements superposés dans les séries métasédimentaires de l'enveloppe. Implications pour tout modèle géodynamique. Géologie de la France 4.

Demange, M. 1999: Évolution tectonique de la Montagne Noire: un modèle en transpression, Comptes rendus de l'Académie des Sciences 329-2a.

Demange, M., Herrera Urbina, S. 1989: Relations entre la Zone axiale et les nappes de la Montagne Noire (Massif Central français): l'exemple des écaillages de la région de Saint-Gervais-sur-Mare. Comptes rendus de l'Académie des Sciences 308-2.

Derruau, M. 1999: The quintessential systematist: Henri Baulig. Geomorphology 11-1. DOI: http://dx.doi.org/ 10.1016/0169-555X(94)90039-6

Devaere, L., Clausen, S., Javier Álvaro, J., Peel, J. S., Vachard, D. 2014: Terreneuvian Orthothecid (Hyolitha) digestive tracts from Northern Montagne Noire, France; taphonomic, ontogenic and phylogenic implications. PLoS ONE 9-2. DOI: http://dx.doi.org/10.1371/journal.pone.0088583

Devaere, L., Clausen, S., Monceret, E., Tormo, N., Cohen, H. 2014: Lapworthellids and other skeletonised microfossils from the Cambrian Stage 3 of the northern Montagne Noire, southern France. Annales de paléontologie 100.

Devaere, L., Clausen, S., Steiner, M., Javier Álvaro, Vachard, D. 2013: Chronostratigraphic and paleogeographic significance of an early Cambrian microfauna from the Heraultia Limestone, northern Montagne Noire, France. Palaeontologia electronica 16-2. 
Dufrénoy, A., Élie de Beaumont, L. 1841: Explication de la carte géologique de la France. Paris.

Ebert, K. 2009: Terminology of long-term geomorphology: a Scandinavian perspective. Progress in physical geography 33-2. DOI: http://dx.doi.org/10.1177/0309133309338138

Ellenberger, F., Latouche, L. 1967: Sur l’enveloppe sédimentaire de la Zone axiale de la Montagne Noire (Monts de Saint-Gervais, Hérault). Comptes rendus sommaires, Société géologique de France.

Ellenberger, F., Santarelli, N. 1974: Les »Schistes X« de la Montagne Noire orientale: distinction d’unités lithostratigraphiques et conséquences tectoniques. Comptes rendus de l’Académie des Sciences 278.

Engel, W., Feist, R., Franke, W. 1978: Synorogenic gravitational transport in the Carboniferous of Montagne Noire (S-France). Zeitschrift der Deutchen Geologische Geselschaft. 129.

Engel, W., Feist, R., Franke, W. 1981: Le Carbonifère anté-stéphanien de la Montagne Noire: rapports entre mise en place des nappes et sédimentation. Bulletin BRGM 2-1.

Faure, M., Cocherie, A., Bé Mézème, E., Charles, N., Rossi, P. 2010: Middle Carboniferous crustal melting in the Variscan Belt: New insights from $\mathrm{U}-\mathrm{Th}-\mathrm{Pb}_{\text {tot. }}$ monazite and $\mathrm{U}-\mathrm{Pb}$ zircon ages of the Montagne Noire Axial Zone (southern French Massif Central). Gondwana Research 18. DOI: http://dx.doi.org/ 10.1016/j.gr.2010.02.005

Faure, M., Cocherie, A., Gaché, J., Esnault, C., Guerrot, C., Rossi, P., Wei, L., Qiuli, L. 2014: Middle Carboniferous intracontinental subduction in the Outer Zone of the Variscan Belt (Montagne Noire Axial Zone, French Massif Central): multimethod geochronological approach of polyphase metamorphism. Geological Society London Special publications 405. DOI: http://dx.doi.org/10.1144/SP405.2

Faure, M., Lardeaux, J.-M., Ledru, P. 2009: A review of the pre-Permian geology of the Variscan French Massif Central. Comptes rendus Geoscience 341.

Favory, M., Gazelle, F. 1982: Modelé karstique et comportement hydrologique des calcaires primaires dans le sud du Massif Central. Revue de géographie des Pyrénées et du Sud-Ouest 52.

Feist, R., Galtier, J. 1984: Découverte de flores d'âge namurien probable dans le flysch à olistolites de Cabrières (Hérault). Implications sur la durée de la sédimentation synorogénique dans la Montagne Noire (France méridionale). Comptes rendus de l'Académie des Sciences 300-2.

Fonteilles, M., Guitard, G. 1977: Influence des noyaux de socle précambrien sur le métamorphisme et la structure profonde de lorogène hercynien des Pyrénées orientales. Comparaison avec les régions voisines. La chaîne varisque d'Europe moyenne et occidentale. Paris.

Gazelle, F. 1979: L'hydrologie karstique et ses problèmes en Montagne Noire occidentale. Revue du Tarn 93. Géoportail. Internet: http://www.geoportail.gouv.fr/accueil (20.2.2015).

Gèze, B. 1949a: Étude géologique de la Montagne Noire et des Cévennes méridionales. Mémoire de la Société géologique de France. Paris.

Gèze, B. 1949b: Carte géologique de la Montagne Noire et des Cévennes méridionales au 1/200.000, et Notice explicative. Montpellier.

Gèze, B. 1971: Carte géologique de France à 1/80.000, Feuille Bédarieux (232).

Gèze, B. 1979: Languedoc méditerranéen. Paris.

Giusti, C. 2002: Le Sud du Massif Central (France). Implications morphogénétiques de l'activation d'une marge passive: approches épistémologique et naturaliste. $\mathrm{PhD}$, University of Perpignan Via Domitia, Perpignan.

Giusti, C. 2012: Du syndrome de Playfair au paradoxe de Penck. HDR, University of Perpignan Via Domitia, Perpignan.

Giusti, C., Calvet, M. 2010: Linventaire des géomorphosites en France et le problème de la complexité scalaire. Géomorphologie: relief, processus, environnement 2.

Giusti, C., Calvet, M., Gunnell, Y. 2013: Géotope, géofaciès et géosystème: une grille de lecture des paysages géomorphologiques? Le cas de la Réserve naturelle nationale des Aiguilles Rouges, Chamonix Mont-Blanc (Haute-Savoie, France). Collection Edytem 15.

Gray, M. 2013: Geodiversity. Valuing and conserving abiotic nature. Chichester.

GSSP for Famennian Stage. Internet: http://www.stratigraphy.org/GSSP/Famennian.html (15. 1. 2014).

GSSP for Frasnian Stage. Internet: http://www.stratigraphy.org/GSSP/Frasnian.html (15. 1. 2014).

GSSP for Tournaisian Stage. Internet: http://www.stratigraphy.org/GSSP/Tournaisian.html (15. 1.2014).

Howe, J. Portfolio. Internet: http://www.john-howe.com/portfolio/gallery/details.php?image_id=106 (15.9.2014). 
Klein, C. 1999: Henri Baulig (1877-1962). Sa contribution à l’enrichissement de la géomorphologie générale. Paris.

Laumonier, B., Autran, A., Barbey, P., Cheilletz, A., Baudin, T., Cocherie, A., Guerrot, C. 2004: Conséquences de l'absence de socle cadomien sur lâge et la signification des séries pré-varisques (anté-Ordovicien supérieur) du sud de la France (Pyrénées, Montagne Noire), Bulletin de la Société géologique de France 175.

Lauterbrunnen illustration.jpg. Internet: http://en.wikipedia.org/wiki/Lauterbrunnen\#/media/File:Sommer, Giorgio_\%281834-1914\%29_-_n._12816_-_Lauterbrunnenthal.jpg (15.9.2014)

Le Griel, A. 1988: La genèse des reliefs du Massif Central. Propos autour d'une prochaine soutenance de thèse. Bulletin du Laboratoire rhodanien de géomorphologie 21-22.

Lorenz, J., Féraud, J. 2004: Pierres du patrimoine. Géochronique 89.

Malavieille, J. 2010: Impact of erosion, sedimentation, and structural heritage on the structure and kinematics of orogenic wedges. Analog models and case studies. GSA Today 20-1.

Marbres de France. Internet: http://www.marbres-de-france.fr/carriere-marbre-france (15.9. 2014).

Martonne, E. de. 1942: Géographie universelle. France physique. Paris.

Ollier, C., 1991: Ancient landforms. London.

Prian, J.-P., 1980: Les phosphorites cambriennes du Versant septentrional de la Montagne Noire au sud du basin permien de Camarès (Aveyron). PhD, Université Pierre-et-Marie-Curie. Paris.

Reynard, E. 2009: The problem of scale in geomorphosites studies. Geomorphosites 2009: Raising the profile of geomorphological heritage through iconography, inventory and promotion, 2012. Paris.

Rivendell illustration.jpg. Internet: http://en.wikipedia.org/wiki/Rivendell\#mediaviewer/File:Rivendell_ illustration.jpg (15.9.2014).

Roger, F., Respaut, J.-P., Brunel, M., Matte, P., Paquette, J.-L. 2004: Première datation U-Pb des orthogneiss œillés de la zone axiale de la Montagne noire (Sud du Massif central): nouveaux témoins du magmatisme ordovicien dans la chaîne Varisque. Comptes rendus Geoscience 336. DOI: http://dx.doi.org/10.1016/ j.crte.2003.10.014

Roger, F., Teyssier, C., Respaut, J.-P., Rey, P.-F., Jolivet, M., Whitney, D.L., Paquette, J.-L., Brunel, M. 2015 : Timing of formation and exhumation of the Montagne Noire double dome, French Massif Central. Tectonophysics 640-641. DOI: http://dx.doi.org/10.1016/j.tecto.2014.12.002

Stampfli, G. M., Hochard, C., Vérard, C., Wilhem, C., von Raumer, J. 2013: The formation of Pangea. Tectonophysics 593. DOI: http://dx.doi.org/10.1016/j.tecto.2013.02.037

Thoral, M. 1935a: Contribution à létude géologique des Monts de Lacaune et des terrains cambriens et ordoviciens de la Montagne Noire. Bulletin du Service de la carte géologique de la France. Paris.

Thoral, M. 1935b: Contribution à l'étude paléontologique de l'Ordovicien inférieur de la Montagne Noire et révision sommaire de la faune cambrienne de la Montagne Noire. Montpellier.

Tolkien, J. R. R. 1937: The Hobbit or There and back again. London.

Tolkien, J. R. R. 1981: The Letters of J. R. R. Tolkien. A selection edited by H. Carpenter, with the assistance of C. Tolkien. London. 